https://doi.org/10.31470/2706-7904-2020-15-95-99

\title{
ДИСКУРСИВНО-КОМПЕТЕНТНІСНІ АСПЕКТИ ПІДГОТОВКИ МАЙБУТНІХ ПСИХОТЕРАПЕВТІВ У ПСИХОЛОГІЧНИХ І МЕДИЧНИХ ЗВО УКРӒ̈НИ
}

Discursive and Competence Aspects of Training the Future Psychotherapists in Psychological and Medical Higher Schools of Ukraine

\author{
Heorhiy Kalmykov \\ DSc. in Psychology, Associate Professor \\ Pereiaslav-Khmelnytskyi Hrihorii Skovoroda State Pedagogical University (Ukraine) \\ kalmykov.gv@ukr.net \\ https://orcid.org/0000-0002-1378-5236

\section{Stefaniya Dobroskok} \\ Postgraduate Student \\ Pereiaslav-Khmelnytskyi Hrihorii Skovoroda State Pedagogical University (Ukraine) \\ https://orcid.org/0000-0002-7590-9193
}

\begin{abstract}
The article actualizes the role of psycholinguistics in the development of the theory and practice of psychotherapy; differences between psychologists and psychotherapists are established; the significance of the provisions of psycholinguistics in the formation of discursive competence and communicative tolerance of future psychotherapists is shown.
\end{abstract}

Key words: psycholinguistics, psychotherapy, psychology, medical and psychological training of future psychotherapists.

\section{Ветуп \\ Introduction}

Поняття психотерапія об'єднує під собою всю різноманітну гаму способів лікування за допомогою мовних засобів і дій, але провідним способом лікування все ж таки залишаються вербальні засоби. 3 огляду на це виникає важливе наукове завдання - з'ясувати роль психолінгвістики у вирішенні проблем мовленнєвого спілкування психотерапевта і клієнта, аналізу психотерапевтичних дискурсів, значення i 
смислу в процесах психотерапевтичної комунікації, мовної, мовленнєвої і дискурсивної компетентності та комунікативної толерантності провізора й інших проблем.

\section{Методи дослідження \\ Methods of the Research}

Використовувалися як теоретичні методи (системний аналіз літературних джерел, узагальнення результатів аналізу) для вивчення стану досліджуваної проблеми, так і емпіричні методи (аналіз стандартів вищої освіти, навчальних планів i навчальних посібників, узагальнення даних емпіричного матеріалу) для виявлення стану використання психолінгвістичних здобутків у підготовці майбутніх психотерапевтів.

\section{Результати \\ Results}

Психотерапія з'явилася на перетині психіатрії та психології. Тому більшість із засновників психотерапії на зорі їі формування були лікарями, і здебільшого членами Міжнародної психоаналітичної асоціації. Крім того, загальновідомо, що засновниками відомих психотерапевтичних напрямків і шкіл були також саме лікарі загального профілю, неврологи, психіатри, а також психологи і один історик, який закінчив курси з психології. Довгий час вважалося, що психотерапія - розділ медицини, і нею може займатися тільки лікар. Це було головним правилом. Психотерапія з'явилася як альтернатива психіатрії XIX століття, яка в той час не мала арсеналу ліків. Таким чином, психотерапія формувалася як лікування психічних порушень без ліків - як лікування вербальними засобами, тому від початку свого становлення була психолінгвістично орієнтованою, хоча й для багатьох їі засновників психолінгвістичний аспект психотерапії не був предметом їхнього аналізу й усвідомлення. 3 огляду на відсутність у засновників психотерапії як лікування словом об’єктивізації психолінгвістичних феноменів, вони розвивали психотерапію лише як психологічний напрямок науки та практичної діяльності психотерапевтів і психоаналітиків.

У даний час лікування тільки словом здійснюється в психоаналізі, груповому аналізі, когнітивно-поведінковій психотерапії, клієнт-психотерапії Роджерса, аналітичній психотерапії Юнга, трансактному аналізі Берна, екзистенційному аналізі тощо. Лікування словом і дією - в дитячому психоаналізі, психодрамі, гештальт- 
терапії, тілесно-орієнтованій психотерапії, танцювально-руховій психотерапії, арттерапії тощо.

У чому в даний час різниця між психологами і лікарями, які надають психотерапевтичні послуги? Передусім відмінності між психологом і лікарем - у площині отриманої ними освіти.

Сучасні психологічні факультети дають всебічну, потрібну для майбутнього психотерапевта, освіту. Серед сукупності багатьох психологічних дисциплін, необхідних для якісної підготовки майбутніх психотерапевтів, обов'язковими є й такі, як клінічна психологія, психологія особистості, психологія розвитку, психогенетика, психофізіологія ЦНС, фізіологія ЦНС, ВНД і сенсорної системи, гормональна регуляція психічних станів, психопатологія, основи психотерапії, психологічне консультування, психодіагностика, тренінгова робота та інші дисципліни, орієнтовані на успішну психотерапевтичну діяльність майбутніх психологів.

Не тільки ці, а й інші дисципліни, що вивчаються у психологічних ЗВО певною мірою готують студентів до психотерапевтичної діяльності. Проте істотним недоліком сучасної підготовки майбутніх психотерапевтів на психологічних факультетах за спеціальністю 053 Психологія (спеціалізація «психотерапія», «психоаналіз», «клінічна психологія») є відсутність дисциплін, вивчення яких сприяє формуванню у студентів професійно-мовленнєвих умінь, навичок i психотерапевтично-дискурсивної компетентності. Більше того, у психотерапевтичній практиці відсутні як рекомендації з дискурсивної практики психотерапевтів, так і засоби оцінювання таких мовленнєво-вербальних - фахових здобутків психотерапевтів. Власне й самі психотерапевти відчувають труднощі вибору доречних мовних засобів у комунікації з клієнтами/пацієнтами, не володіють тим репертуаром мовленнєвих форм i структур, який би допомагав їм безперешкодно виражати свої психотерапевтичні смисли, думки та інтенції. Відтак, виникає парадоксальна ситуація: відбувається навчання психотерапії як навчання лікування словом, а формування у студентів відповідних мовленнєво-вербальних умінь, навичок i компетентностей не передбачається змістом психологічної освіти.

Щодо підготовки майбутніх психотерапевтів у медичних 3ВО, то медики в процесі свого навчання вивчають лише такі психологічно орієнтовані дисципліни, якот: неврологія, наркологія, психіатрія, а також основи психології, медичну психологію тощо. На дисципліну «основи психотерапії» в медвузах, як правило, не виділяються кредити. Питання щодо дискурсивно-компетентнісної і комунікативнотолерантнісної підготовки студентів-медиків - майбутніх психотерапевтів - не піднімається взагалі. Як можна бачити, в медичних ЗВО залишається зовсім небагато часу на предмети, потрібні для професійної підготовки психотерапевта. 
3 огляду на вищезазначене виникає закономірне запитання: хто сьогодні має право працювати психотерапевтом? В Україні згідно із законодавством психотерапевтом може стати або лікар, або психолог (за кордоном таку можливість мають ще соціальні працівники, іноді філософи). Для того, щоб уточнити дійсний статус психотерапевта, якого традиційно пов'язували з медициною, варто з'ясувати, яку кваліфікацію за спеціалізацією він отримав. Якщо випускник має крім основної лікарської кваліфікації ще й додаткову кваліфікацію «психотерапевт», а випускникпсихолог крім основної психологічної, ще й додаткові кваліфікації або «психотерапевт», або «психоаналітик», то такі фахівці можуть працювати в галузі психотерапії і надавати психологічну допомогу населенню України.

Але, ні базова освіта психолога, ні базова освіта лікаря самі по собі не $є$ сьогодні достатніми, щоб займатися психотерапією. Тільки той психолог або той лікар, який має психологічну або медичну освіту з відповідною спеціалізацією або продовжив свою освіту, пройшовши професійну перепідготовку для отримання юридичного права практикувати в області психотерапії, може працювати психотерапевтом. Це стосується і наукових ступенів (доктор філософії/кандидат або доктор наук), а також кафедральних посад і вчених звань у ЗВО (доцент чи професор), дипломи i атестати яких не підтверджують кваліфікацію в практичній психотерапевтичній галузі.

Навчання психотерапії (спеціалізація у 3ВО, або перепідготовка) триває кілька років. Будь-яка короткотривала перепідготовка психотерапевтів, яка займає лише кілька місяців, звичайно, не може вважатися професійною й ефективною. Як приклад навчання танцювальної психотерапії, яка в окремих 3ВО в цілому триває до 4-х років.

Особливого сенсу також набувають довготривалі терміни навчання в тих видах психотерапії, в основі яких лежать вербальні засоби. 3 огляду на це короткий цикл перепідготовки не тільки засвідчує «несерйозність» підходу, а й в деякому сенсі $\epsilon$ шкідливим як для психотерапевта, який має амбіції професіонала, так і в першу чергу для клієнта/пацієнта, який не зможе отримати потрібного для його лікування вербального втручання у психічні сфери. Мовленнєво-мовні навички і дискурсивні компетентності, врай необхідні і потрібні для лікування словом, не формуються за кілька місяців. Для оволодіння ними, як засвідчує досвід експериментальної роботи, потрібно значно більше часу, на кшталт хоча б терміну підготовки магістрів. Обмежитися при підготовці психотерапевтів лише формуванням знань про цей вид психологічної допомоги - означає випустити фахівця, який знає, але не вміє і не здатний комунікувати 3 клієнтом, вибираючи доречні і вкрай необхідні для лікування клієнта слова і мовленнєві фрази, не спроможний вербально вплинути на психіку людей, котрі потребують психологічної допомоги. Отже, цей психолінгвістичний 
аспект психотерапії потребує особливої уваги як науковців, так і тих, хто здійснює підготовку психотерапевтів.

Нами розроблено спеціальний, психолінгвістично центрований, курс, розрахований на 6 кредитів із навчання у ЗВО магістрантів за спеціальністю 053 Психологія (спеціалізація - «психотерапія»). Основна мета цієї психолінгвістичної дисципліни - формування професійно-мовленнєвої діяльності психотерапевта, розвиток психотерапевтично-дискурсивних умінь, навичок i компетентностей. Закінчивши магістратуру, майбутні психотерапевти, опанувавши цей курс, оволоділи метамоделями психотерапевтичних дискурсів і дискурсивними психотехніками, а саме способами дискурс-запитань, дискурс-заохочень, дискурс-конфронтацій, дискурс-інформувань, дискурс-номінацій емоцій та почуттів, дискурс-інтерпретувань, дискурс-саморозкриття, дискурс-керування, дискурс-підтримки, дискурс-відображень когнітивного змісту та ін.

\section{Висновки \\ Conclusions}

Який би аспект фахової i психолінгвістичної діяльності досвідченого психотерапевта або підготовки майбутніх психотерапевтів не розглядався, в будьякому випадку фахівці психотерапевтичного профілю мають справу 3 психолінгвістичними феноменами: внутрішнім мовленням, дискурсами, смислами i значеннями, генерацією мовлення, комунікацією, мовленнєвим спілкуванням, сприйманням і розумінням клієнтів тощо. Тому питання про психолінгвістичну підготовку майбутнього психотерапевта й урахування психолінгвістичних положень у роботі практикуючих психотерапевтів $є$ в даний час одним з найважливіших завдань як психологічної науки, так і психотерапевтичної практики. 